\title{
Occurrence of Cryptosporidium and Helminthosis in Santa Ines Sheep under Dry and Rainy Season
}

\author{
Bueno da Silva Abreu ${ }^{1}$, Carlos Syllas Monteiro Luz ${ }^{2}$, Ronaldo do Ò Santos ${ }^{3}$, Marcelo Richelly Alves de Oliveira ${ }^{2}$, \\ Geraldo Magela Côrtes Carvalho ${ }^{4}$, Leonardo Atta Farias ${ }^{5}$, Severino Cavalcante de Sousa Júnior ${ }^{5}$ \\ $\&$ Karina Rodrigues dos Santos ${ }^{2}$ \\ ${ }^{1}$ Pós-graduação em Zootecnia, Universidade Federal Rural de Pernambuco, Brazil \\ ${ }^{2}$ Pós-graduação em Ciência Animal, Universidade Federal do Piauí, Teresina, Piauí, Brazil \\ ${ }^{3}$ Graduação em Medicina Veterinária, Universidade Federal do Piauí, Bom Jesus, Piauí, Brazil \\ ${ }^{4}$ Pesquisador, Embrapa Meio Norte, Teresina, Piauí, Brazil \\ ${ }^{5}$ Pós-graduação em Zootecnia, Universidade Federal do Piauí, Bom Jesus, Piauí, Brazil \\ Correspondence: Carlos Syllas Monteiro Luz, Departamento de Zootecnia, Universidade Federal do Piauí, \\ Teresina, PI, 64049-830, Brazil. Tel: 55-89-8116-4119. E-mail: syllaszoot@yahoo.com.br
}

Received: February 2, 2017

Accepted: March 6, 2017 Online Published: June 15, 2017

doi:10.5539/jas.v9n7p39

URL: https://doi.org/10.5539/jas.v9n7p39

\begin{abstract}
Cryptosporidiosis is a parasitic disease caused by a protozoan from the genus Cryptosporidium with cosmopolitan distribution and zoonotic potential. The objective of this work was to determine the occurrence of Cryptosporidium and helminthosis in Santa Ines sheep herd during dry and rainy season. This work was developed at the sheep's breeding sector from the Federal University of Piaui, located in Southern Piauí, Brazil. Fifty sheep kept in a semi-intensive system were used in the experiment using the method according Ritchie, Ziehl-Neelsen and Gordon and Whitlock. Cryptosporidium oocysts were detected in $36 \%$ of the animals tested, with 20 males exhibiting a percentage of 50\% (10 animals) protozoan in the feces and 50\% (10 animals) exhibiting negative results. Among the 30 tested females, 8 (26.6\%) were positive and $22(73.4 \%)$ were negative. Concerning the age, 24 animals (48\%) were of 0-12 months old, with prevalence of $11(46 \%)$ positive animals showing protozoan in the feces, and 26 animals (52\%) between 13-48 months old. The rainy season showed the highest counting of eggs per gram of feces (EPG), reaching a mean value of 2250 thus, a high occurrence of Cryptosporidium was evidenced, with a higher infection degree in young male sheep, predominantly during the rainy season, when a higher EPG was observed.
\end{abstract}

Keywords: protozoan, cryptosporidiosis, zoonosis

\section{Introduction}

Cryptosporidiosis is a parasitic zoonosis with global distribution, caused by a protozoan from the genus Cryptosporidium (Ederli, Carvalho, \& Sales, 2004), which may infect different hosts, including mammals like humans; as well as birds, reptiles, amphibians and fishes (Thompson \& Monis, 2012; García-Presedo et al., 2013; Santin, 2013; Bouzid et al., 2013; Slapeta, 2013). This is an opportunistic intracellular obligate parasite that completes its biological cycle in the surface of epithelial cells of the respiratory and gastrointestinal tract, being responsible for the syndrome of the aqueous diarrhea, dehydration, abdominal pain, weight loss, delayed growth and death (Rieux et al., 2013).

These are considered not species-specific parasites, thus the transmission from different animal species to humans is possible to occur. The oocyst, the infecting stage, is released with the feces and remains steady for many months; being the fecal-oral considered as the main transmission path. Ingested by the host, the oocyst invades the epithelium, replicates, and through sequential reproductive cycles may result in the release of thousands of parasites per day via feces. The transmission is associated with water intake, food ingestion and contact with infected animals and/or humans (Smith et al., 2007; Dixon et al., 2011; Zucatto et al., 2015).

In domestic animals the highest prevalence of infection is found in cattle herds, especially the youngest, with records of mortality among small ruminants (Dixon et al., 2011). The most studied is the bovine species, with 
morbidity varying from 10 to $85 \%$ due to $C$. parvum, especially among calves, with high morbidity rates when occurring in association with other infectious agents, deficient nutrition and immunosuppression (Fayer, Morgan, \& Upton, 2006; Quadros et al., 2006; Thomaz et al., 2007).

In sheep, Cryptosporidium infection was first described in Australia, in animals from one to three weeks old exhibiting diarrhea (Barker \& Carbonell, 1974; Dixon et al., 2011). Its role as a primary agent was confirmed in experiments performed in the beginning of 1980 (Snodgrass, Angus, \& Gray, 1984). Causape et al. (2002) reported 59\% prevalence of Cryptosporidium spp., in lambs with diarrhea, the prevalence was of $79.4 \%$ when compared with animals without diarrhea (22.4\%). Santin, Trout, and Fayer (2007) reported prevalence of 25\% and $77.4 \%$, respectively, in sheep and lambs. Castro-Hermida et al. (2007) diagnosed 5.3\% sheep eliminating oocysts of Cryptosporidium spp.

According Green, Amarante and Mascarini, (2004) the occurrence of Cryptosporidium was associated with rainfall, this authors reported that the highest prevalence of Cryptosporidium oocysts coincided with the rainy months of the year, while studying 184 samples obtained during the period of highest precipitation (more than $150 \mathrm{~mm} / \mathrm{month}$ ), when $102(55.4 \%)$ animals showed Cryptosporidium oocysts, while only 31 (17.3\%) of the 179 samples taken during the period with low rainfall (less than $100 \mathrm{~mm} / \mathrm{month}$ ) were positive.

In the State of Rio de Janeiro, Brazil, Santa Inês sheep were positive for Cryptosporidium spp. oocysts (Cosendey et al., 2008b). Vieira et al. (2008) observed that sheep during spring had higher values of EPG due to the increase of rain precipitation and average temperatures of $20^{\circ} \mathrm{C}$, favorable to the nematodes.

The infection in humans and various animal species constitutes a public health issue, that is why, detection of this parasite in animal feces is important, due to the capacity of ruminants being a source of infection for humans (Ryan, Fayer, \& Xiao, 2014; Paz e Silva et al., 2014). Due to the growing significance of cryptosporidiosis as a zoonotic parasitic infection, the present work had the objective to access the occurrence of coccidian of the genus Cryptosporidium and helminthes in fecal samples from sheep.

\section{Method}

\subsection{Study Area and Ethical Issues}

The study was performed at the sheep's breeding sector from the Bom Jesus' Technical School (CTBJ) from the Federal University of Piauí (UFPI), Campus Professora Cinobelina Elvas in Bom Jesus, Piauí, Brazil, during a dry and rainy season in December 2011 and March and June 2012.

The region has a mean temperature of $27^{\circ} \mathrm{C}$ and mean annual rainfall of $1,000 \mathrm{~mm}$, with a dry season extending from May to November and a rainy season from December to April (Luz et al., 2014). The experiments were approved by the Ethics Committee on Animal Experimentation under the protocol number 034/2011.

\subsection{Animals and Data Collecting}

Fifty sheep from the Santa Ines' breed were randomly selected, being 20 male and 30 female individuals that were properly identified using rings or collars. Within the sample population the age of 24 ovine (10 males and 14 females) varied from 0-12 months old and 26 ovine (10 males and 16 females) from 13-48 months old. Samples were collected in two different periods of the year from all animals: once during the dry season and once during the rainy season.

The animals were growth on pasture under a semi-intensive system with the herd spending the day in paddocks of 50 hectares formed by mixed grazing Brachiaria decumbens and grass Andropogon (Andropogon gayanus cv. Planaltina), late in the afternoon animals were allocated in collective bails and fed with concentrated supplement with $40 \%$ bran corn, $15 \%$ soybean meal, $10 \%$ urea, $30 \%$ of salt and $5 \%$ limestone, mineral supplementation and water ad libitum. All animals were dewormed every four months with Dectomax. These animals were identified and the date was recorded in individual files.

Individual fecal samples were taken weekly, directly from the ampulla of the rectum and stored in plastic bags, in order to avoid contamination by free-living larvae (Cosendey et al., 2008a; Romero-Salas et al., 2016). Samples were properly conditioned in thermal bags containing ice in order to preserve samples until processing at the Laboratory of Veterinary Parasitology of the Federal University of Piauí, Brazil.

\subsection{Parasitological Analysis of Faeces Samples}

In order to evaluate oocysts of Cryptosporidium spp. the methods according Ritchie (1948), modified for oocyst's concentration and Ziehl-Neelsen (Henriksen \& Pohlenz, 1981), modified for oocyst's staining, were used. In addition to identification, the number of eggs per gram of feces (EPG) were evaluated according Gordon and Whitlock (1939). 


\subsection{Formol-Ether Technique (Ritchie, 1948)}

For the analysis, $1 \mathrm{~g}$ of feces in $4 \mathrm{ml}$ of buffered saline solution was weighed, then this solution was filtered in folded gauze and transferred to $6 \mathrm{ml}$ glass tubes, which were completed with saline solution up to the edge. Tubes were then centrifuged at $500 \mathrm{rpm}$ for 8 minutes, in a Sislab/Tister centrifugue, then the supernatant was eliminated and tubes completed again with buffered saline solution before centrifuged at $500 \mathrm{rpm}$ for 8 minutes. Then the supernatant was discarded and $3 \mathrm{ml}$ of cooled ether was added, then each tube was vigorously homogenized for 30 seconds, and centrifuged again at $500 \mathrm{rpm}$ for 8 minutes.

Four layers resulted from this procedure: solvent, saline solution, fecal remains, and sediments containing oocysts of Cryptosporidium ssp., the supernatant was again discarded and fine smears were prepared with the remaining fecal residue from the bottom of the tubes. Smears were air-dried at room temperature and fixed in methanol for 3 minutes, similar to the procedure adopted by Cosendey et al. (2008a, 2008b).

\subsection{Procedure of Ziehl-Neelsen Modified Staining (Henriksen \& Pohlenz, 1981)}

To stain the smears a carbol fuchsine solution was used for 20 minutes, followed by washing in running tap water, until the excess of fuchsine was removed, and then the alcohol-sulfuric acid solution was added for 1 minute until the excess of dye was removed, then the smears were finally washed again in running tap water and dried at room temperature.

The smears were counterstained with methylene blue for 5 minutes, washed and air-dried at room temperature. Smears were observed with the aid of light microscope with a $100 \times$ objective and immersion oil, oocysts stained by fuchsine were shown with a pink to bright red color against a blue background.

\subsection{Gordon and Whitlock (1939) Modified Method}

In order to evaluate the number of eggs per gram of feces, $2 \mathrm{~g}$ of feces were weighted in a plastic cup. Then, with the aid of a graduated cylinder, $58 \mathrm{ml}$ of a saline solution were added gradually to the homogenized feces to facilitate mixing. The homogenized was filtered into another cup using gauze and then vigorously homogenized with the aid of a glass rod.

The results obtained using both techniques were registered in spreadsheets and submitted to a Prevalence analysis using the software Microsoft Excel ${ }^{\circledR}$, to verify the results and create graphics.

\section{Results and Discussion}

Oocyts of Cryptosporidium spp. were detected in 50 samples from Santa Inês sheep, 20 males (50\%) showed Cryptosporidium spp. oocysts and 10 animals (50\%) were considered as negative. Among the 30 examined females, $8(26.6 \%)$ had positive results for the protozoa in their feces and $22(73.4 \%)$ had negative results (Table 01). Similar prevalence values were observed in previous studies, as in Paz e Silva et al. (2014) found 25 sheep positive for Cryptosporidium (25\%) and Cosendey et al. (2008a) while working in the micro-region of Campos dos Goytacazes, in the state of Rio de Janeiro, Brazil, where the authors observed oocysts of Cryptosporidium spp. in $47 \%$ of the 130 animals examined.

Tabela 1. Prevalence of male and female sheep parasited by protozoan of the genus Cryptosporidium and detected by the Ziehl-Neelsen modified technique

\begin{tabular}{llll}
\hline Variables & Positive & Negative & Total \\
\hline Males, & $10(50 \%)$ & $10(50 \%)$ & $20(40 \%)$ \\
Females & $8(26.6 \%)$ & $22(73.4 \%)$ & $30(60 \%)$ \\
Total & $18(36 \%)$ & $32(64 \%)$ & $50(100 \%)$ \\
\hline
\end{tabular}

Cryptosporidium spp. is a parasite that may infect humans, therefore an important international public health matter (Zucatto et al., 2015). In a previous research developed in Poland with 159 sheep, 16 animals were found parasitized by oocysts of Cryptosporidium using the Ziehl-Neelsen modified method (Majewska et al., 2000). In a similar study developed in Maryland, USA, with 31 sheep, a prevalence of $77.4 \%$ of $C$. parvum was observed using the PCR method (Santin et al., 2007).

In research accomplished in the Northeastern region of Spain by Díaz et al. (2015), 31.6\% pre-weaning lambs were positive form a total of 171 animals tested, showing that Cryptosporidium is a prevalent enteric pathogenic agent widely distributed within small ruminants, similar to the results of $36 \%$ positive samples observed in the present study. This is probably resulting from the sanitary conditions of the facilities, especially when associated 
to the presence of feces and the water quality available to animals, thus leading to an increase in the infection pressure and transmission of the protozoan.

The Prevalence of Cryptosporidium spp. was higher in young animals, within a total of 50 animals studied, $48 \%$ (2) were between 0-12 months old, with $46 \%$ (11) of these animals having the protozoan in the feces and $52 \%$ (26) were between 13-48 months old with 27\% (7) of these animals showing oocysts in their feces (Figure 1). Younger animals are more susceptible to the neonatal diarrhea syndrome due to the immunosuppression vastly associated to high mortality rates (Goma et al., 2007).

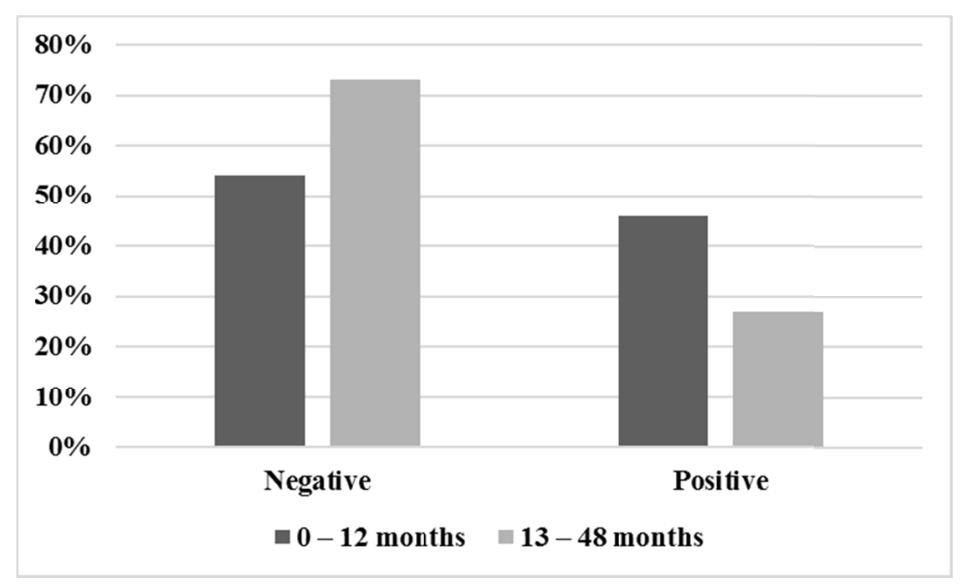

Figure 1. Prevalence of Cryptosporidium spp. in sheep with ages between 0-12 months and 13-48 months

Majewska et al. (2000), using the Ziehl-Neelsen modified method, also observed that younger animals were more parasitized than older ones. In Australia, Ryan et al. (2005), while studying 500 fecal samples from sheep using the polymerase chain reaction (PCR) method also observed a higher prevalence $(26.2 \%)$ in younger animals. However, Alonso-Fresán et al. (2005) observed no correlation between the protozoan prevalence and sheep age.

The fact of animals allocated in the late afternoon and early morning in a collective stall being more susceptible to the parasite may be explained once under such system animals remained inside the facilities, thus favoring dissemination of the protozoan due to the accretion of wastes along with the increment of humidity, favoring the life cycle of this protozoan (Causape et al., 2002; Bomfim et al., 2005). In the present study different rates of infection were observed in different months of the year.

The first samples were collected in December and March (Figure 2), a period with high concentration of rain and high humidity, a propitious environment to the parasite's development. During this period 11 (22\%) of the total animals examined showed oocysts of Cryptosporidium spp. in the feces, with values for mean number of trichostrongylids' eggs reaching 2250 EPG, in accordance with Vieira et al. (2008) who also observed higher values for EPG during the months of March and June, but differing from the results obtained by Nieto et al. (2003), who observed 500 EPG during March in Gaúcha, northwest region of Paraná, Brazil, a difference that may be attributed to climatic discrepancies between the Northeastern and Southern regions in Brazil. 


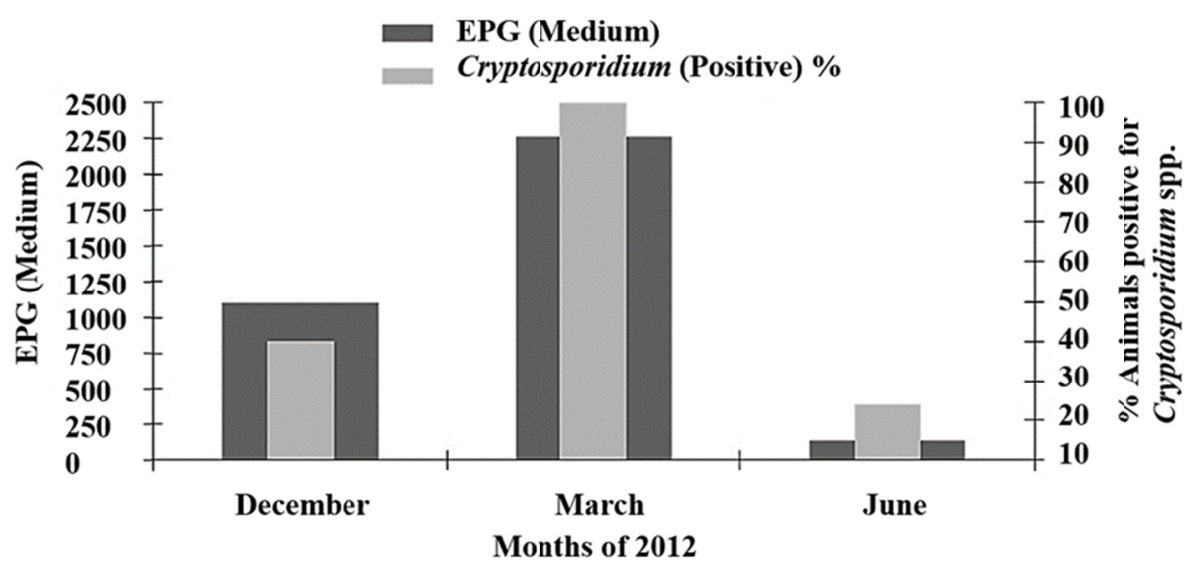

Figure 2. Percentage of Cryptosporidium spp. occurrence and mean number of EPG from sheep according to the period of the year

Another set of samples were collected in June, a period with low intensity of rain fall and low relative humidity. During this period 14\% (7) animals were found parasitized by oocysts of Cryptosporidium spp., that is to say, a lower prevalence of oocysts was detected during the dry season when compared to the rainy season, agreeing with previous studies as in Costa, Simões, and Riet-Correa (2011), who argue that high temperatures, may at the same time accelerate the parasite's development and reduce their surviving time in the environment.

Simultaneously to the copro-parasitological survey to study Cryptosporidium spp. by the Ziehl-Neelsen and Ritchie modified methods, feces of the 50 animals were also analyzed by the Gordon \& Whitlock technique, resulting in a prevalence of $56 \%$ distinctive nematode eggs from the family Trichostrongyloidea. The results showed $22 \%$ (11) animals with presence of nematode eggs and within these, $16 \%$ (8) animals with positive results for Cryptosporidium spp., with 18\% (9) animals within the age of 4-8 months old with an EPG average of 1788 and $4 \%$ (2) animals, one with the age of 18 months old and another with the age of 24 months, both with an average of $600 \mathrm{EPG}$.

\section{Conclusion}

There is a high occurrence of protozoans from the genus Cryptosporidium spp. in Santa Ines sheep, with higher infection rates observed in young male ovines, predominantly during the rainy season, when higher rates of EPG were observed. There are significant numbers of asymptomatic animals.

\section{References}

Ahid, S. M. M., Suassuna, A. C. D., Maia, M. B., Costa, V. M. M., \& Soares, H. S. (2008). Parasitos gastrintestinais em caprinos e ovinos e da região oeste do Rio Grande do Norte, Brasil. Ciência Animal Brasileira, 9(1), 112-218. Retrieved from https://www.revistas.ufg.br/vet/article/view/3681/3449

Alonso-Fresán, M. U., García-Álvarez, A., Salazar-García, F., Vázquez-Chagoyán, J. C., Pesacador-Salas, N., \& Saltijeral-Oaxaca, J. (2005). Prevalence of Cryptosporidium spp. in a asymptomatic sheep in family flocks from Mexico State. Journal of Veterinary Medicine, Series B, 52(10), 482-483. https://doi.org/10.1111/ j.1439-0450.2005.00889.x

Barker, I. K., \& Carbonell, P. L. (1974). Cryptosporidium agni sp. n. from lambs and Cryptosporidium bovis sp. n. from a calf with observations on the oocyst. Parasitology Research, 44(4), 289-298. https://doi.org/ $10.1007 / \mathrm{BF} 00366112$

Bomfim, T. C. B., Huber, F., Gomes, R. S., \& Alves, L. L. (2005). Natural infection by Giardia sp. and Cryptosporidium sp. in dairy goats, associated with possible risk factors of the studied properties. Veterinary Parasitology, 134(1-2), 9-13. https://doi.org/10.1016/j.vetpar.2005.05.067

Bouzid, M., Hunter, P. R., Chalmers, R. M., \& Tyler, K. M. (2013). Cryptosporidium pathogenicity and virulence. Clinical Microbiology, 26(1), 115-134. https://doi.org/10.1128/CMR.00076-12

Castro-Hermida, J., Almeida, U. M., González-Warleta, M., Correia, J. M. C., Rumbo-Lorenzo, C., \& Mezo, M. (2007). Occurrence of Cryptosporidium parvum and Giardia duodenalis in healthy adult domestic ruminants. Parasitology Research, 101(5), 1443-1448. https://doi.org/10.1007/s00436-007-0624-6 
Causape, A. C., Quílez, J., Sánchez-Acedo, C., Cacho, E. D., \& López-Bernad, F. (2002). Prevalence and analysis of potential risk factors for Cryptosporidium parvum infection in lambs in Zaragoza (northeastern Spain). Veterinary Parasitology, 104(4), 287-298. https://doi.org/10.1016/S0304-4017(01)00639-2

Cosendey, R. I. J., Fiúza, V. R. S., Teixeira, C. S., \& Oliveira, F. C. R. (2008a). Freqüência de oocistos de coccídeos do gênero Cryptosporidium em ovinos no Estado do Rio de Janeiro. Revista Brasileira de Saúde e Produção Animal, 9(4), 687-695. Retrieved from http://revistas.bvs-vet.org.br/rbspa/article/view/13292

Cosendey, R. I. J., Fiuza, V. R. S., \& Oliveira, F. C. R. (2008b). Importância do manejo na criptosporidiose em criações de ovinos. Revista Brasileira de Parasitologia Veterinária, 17(1), 209-214. Retrieved from http://cbpv.org.br/rbpv/documentos/17supl.12008/Protozool005.pdf

Costa, V. M. M., Simões, S. V. D., \& Riet-Correa, F. (2011). Controle das parasitoses gastrintestinais em ovinos e caprinos na região semiárida do Nordeste do Brasil. Pesquisa Veterinária Brasileira, 31(1), 65-71. https://doi.org/10.1590/S0100-736X2011000100010

Díaz, P., Quílez, J., Prieto, A., Navarro, E., Pérez-Creo, A., Fernández, G., ... Morrondo, P. (2015). Cryptosporidium species and subtype analysis in diarrhoeic pre-weaned lambs and goat kids from north-western Spain. Parasitology Research, 114(11), 4099-4105. https://doi.org/10.1007/s00436-0154639-0

Dixon, B., Parrington, L., Cook, A., Pintar, K., Pollari, F., Kelton, D., \& Farber, J. (2011). The potential for zoonotic transmission of Giardia duodenalis and Cryptosporidium spp. from beef and dairy cattle in Ontario, Canada. Veterinary Parasitology, 175(1-2), 20-26. https://doi.org/10.1016/j.vetpar.2010.09.032

Ederli, B. B., Carvalho, C. B., \& Sales, L. G. (2004). Ocorrência da infecção por Cryptosporidium em bezerros na Microrregião de Campos dos Goytacazes no Norte do Estado do Rio de Janeiro, Brasil. Revista Brasileira Parasitologia Veterinária, 13(2), 45-48.

Fayer, R., Morgan, U., \& Upton, S. J. (2006). Detection of Cryptosporidium felis and Giardia duodenalis assemblage F in a cat colony. Veterinary Parasitology, 140(1-2), 44-53. https://doi.org/10.1016/j.vetpar. 2006.03.005

García-Presedo, I., Pedraza-Díaz, S., González-Warleta, M., Mezo, M., Gómez-Bautista, M., Ortega-Mora, L. M., \& Castro-Hermida, J. A. (2013). The first report of Cryptosporidium bovis, C. ryanae and Giardia duodenalis sub-assemblage A-II in roe deer (Capreolus capreolus) in Spain. Veterinary Parasitology, 197(3-4), 658-664. https://doi.org/10.1016/j.vetpar.2013.07.002

Goma, F. Y. F. Y., Geurden, T., Siwila, J., Phiri, I. G. K., Gabriel, S., Claerebout, E., \& Vercruysse, J. (2007). The prevalence and molecular characterization of Cryptosporidium spp. in small ruminants in Zambia. Small Ruminant Research, 72(1), 77-80. https://doi.org/10.1016/j.smallrumres.2006.08.010

Gordon, H. Mcl., \& Whitlock, H. V. (1939). A new technique for counting nematode eggs in sheep feces. Journal of the Council for Scientific and Industrial Research, 12(1), 50-52.

Green, R. E., Amarante, A. F. T., \& Mascarini, L. M. (2004). The seasonal distribution of Cryptosporidium oocysts in sheep raised in the State of São Paulo. Revista Brasileira de Parasitologia Veterinária, 13(3), 125-127. Retrieved from http://cbpv.org.br/rbpv/documentos/1332004/c133125_127.pdf

Henriksen, S., \& Pohlenz, I. J. (1981). Staining of cryptosporidia by a modified Zielh-Neelsen technique. Acta. Veterinaria Scandinavica, 22(3-4), 594-596.

Luz, C. S. M., Barros Jr, C. P., Fonseca, W. J. L., Amorim, R. B., Silva, L. A., Lima, L. A., ... Santos, K. R. (2014). Estimativas de características termorreguladoras de ovinos em período seco e chuvoso criados na região do vale do Gurguéia, Sul do Estado do Piaú. Acta Veterinaria Brasilica, 8(1), 19-24. https://doi.org/10.21708/avb.2014.8.1.3233

Majewska, A. C., Werner, A., Sulima, P., \& Luty, T. (2000). Prevalence of Cryptosporidium in sheep and goats bred on five farms in West central region of Poland. Veterinary Parasitology, 89(4), 269-275. https://doi.org/10.1016/S0304-4017(00)00212-0

Nieto, L. M., Martins, E. N., Macedo, F. A. F., \& Zundt, M. (2003). Observações epidemiológicas de helmintos gastrintestinais em ovelhas mestiças manejadas em pastagens com diferentes hábitos de crescimento. Ciência Animal Brasileira, 4(1), 45-51. Retrieved from https://www.revistas.ufg.br/vet/article/view/297 
Paz e Silva, F., Lopes, R., Bresciani, K. D. S., Amarante, A., \& Araujo, J. (2014). High occurrence of Cryptosporidium ubiquitum and Giardia duodenalis genotype E in sheep from Brazil. Acta Parasitologica, 59(1), 193-196. https://doi.org/10.2478/s11686-014-0223-5

Quadros, R. M. D., Marques, S. M. T., Amendoeira, C. R., Souza, L. A., Amendoeira, P. R., \& Comparin, C. C. (2006). Detection of Cryptosporidium oocysts by auramine and Ziehl-Neelsen staining methods. Parasitologia Latino Americana, 61(3-4), 117-120. https://doi.org/10.4067/s0717-77122006000200003

Rieux, A., Chartier, C., Pors, I., Delafosse, A., \& Paraud, C. (2013). Molecular characterization of Cryptosporidium isolates from high-excreting young dairy calves in dairy cattle herds in Western France. Parasitology Research, 112(10), 268-272. https://doi.org/10.1007/s00436-013-3520-2.

Ritchie, L. S. (1948). An ether sedimentation technique for routine stool examinations. Bulletin United States Army. Medical Department, 8(4), 326.

Romero-Salas, D., Alvarado-Esquivel, C., Cruz-Romero, A., Aguilar-Domínguez, M., Ibarra-Priego, N., Merino-Charrez, J. O., ... Hernández-Tinoco, J. (2016). Prevalence of Cryptosporidium in small ruminants from Veracruz, Mexico. Prevalence of Cryptosporidium in small ruminants from Veracruz, Mexico. BMC Veterinary Research, 12(1), 1-6. https://doi.org/10.1186/s12917-016-0638-3

Ryan, U. M., Bath, C., Robertson, I., Read, C., Elliot, A., Mcinnes, L., ... Besier, B. (2005). Sheep may not be an important zoonotic reservoir for Cryptosporidium and Giardia parasites. Applied and Environmental Microbiology, 71(9), 4992-4997. https://doi.org/10.1128/AEM.71.9.4992-4997.2005

Ryan, U., Fayer, R., \& Xiao, L. (2014). Cryptosporidium species in humans and animals: Current understanding and research needs current understanding and research needs. Parasitology, 141(13), 1667-1685. https://doi.org/10.1017/S0031182014001085

Santin, M. (2013). Clinical and subclinical infections with Cryptosporidium in animals, New Zealand. New Zealand Veterinary Journal, 61(1), 1-10. https://doi.org/10.1080/00480169.2012.731681

Santin, M., Trout, J. M., \& Fayer, R. (2007). Prevalence and molecular characterization of Cryptosporidium and Giardia species and genotypes in sheep in Maryland. Veterinary Parasitology, 146(1-2), 17-24. https://doi.org/10.1016/j.vetpar.2007.01.010

Slapeta, J. (2013). Cryptosporidiosis and Cryptosporidium species in animals and humans: A thirty colour rainbow. International Journal for Parasitology, 43(12-13), 957-970. https://doi.org/10.1016/j.ijpara. 2013.07.005

Smith, H. V., Cacciò, S. M., Cook, N., Nichols, R. A., \& Tait, A. (2007). Cryptosporidium and Giardia as foodborne zoonoses. Veterinary Parasitology, 149(1-2), 29-40. https://doi.org/10.1016/j.vetpar.2007.07.015

Snodgrass, D. R., Angus, K. W., \& Gray, E. W. (1984). Experimental cryptosporidiosis in germ-free lambs. Journal of Comparative Pathology, 94(1), 141-152. https://doi.org/10.1016/0021-9975(84)90016-1

Thomaz, A., Meireles, M. V., Soares, R. M., Pena, H. F., \& Gennari, S. M. (2007). Molecular identification of Cryptosporidium spp. from fecal samples of felines, canines and bovines in the state of São Paulo, Brazil. Veterinary Parasitology, 150(4), 291-296. https://doi.org/10.1016/j.vetpar.2007.09.023

Thompson, R. C., \& Monis P. (2012). Giardia-from genome to proteome. Advances in Parasitology, 78, 57-95. https://doi.org/10.1016/B978-0-12-394303-3.00003-7

Vieira, M. I. B., Rocha, H. C., Ractz, L. A. B., Nadal, R., Moraes, R. B., \& Oliveira, I. S. (2008). Comparação de dois métodos de controle de nematódeos gastrintestinais em borregas e ovelhas de corte. Semina: Ciências Agrárias, 29(4), 853-860. https://doi.org/10.5433/1679-0359.2008v29n4p853

Zucatto, A. S., Aquino, M. C. C., Inácio, S. V., Figueiredo, R. N., Pierucci, J. C., Perri, S. H. V., ... Bresciani, K. D. S. (2015). Molecular characterisation of Cryptosporidium spp. in lambs in the South Central region of the State of São Paulo. Arquivo Brasileiro de Medicina Veterinária e Zootecnia, 67(2), 441-446. https://doi.org/10.1590/1678-7067

\section{Copyrights}

Copyright for this article is retained by the author(s), with first publication rights granted to the journal.

This is an open-access article distributed under the terms and conditions of the Creative Commons Attribution license (http://creativecommons.org/licenses/by/4.0/). 